\title{
Diffusivity of Chloride Ion in Mortar Cubes Made Using Ordinary Portland and Portland Pozzolana Cements
}

\author{
Mutitu, D. K. Karanja J. K. and Wachira, J. M. \\ Department of Chemistry, Kenyatta University
}

\begin{abstract}
Cement is subject to degradation by aggressive media. This study investigated chloride diffusivity in mortar made from Kenyan cements which included three brands of Ordinary Portland Cements (OPC) and three brands of Portland Pozzolana Cements (PPC) sampled within Kenyan markets. The test cements were used to make mortar prisms at different water/cement ratios. Compressive strength was determined at the $7^{\text {th }}$ and $28^{\text {th }}$ day of curing. The mortars were subjected to laboratory prepared $3.5 \%$ by mass of sodium chloride solution under accelerated ion migration test method for a period of thirty six hours using a $12 \mathrm{~V} D C$ power source. The compressive strength before subjecting to aggressive media was found to increase with curing duration as well as on decreasing w/c. Compressive strength at all w/c ratios was found to increase after the aggressive media ingress. After subjecting the mortar cubes to $\mathrm{Cl}$ media, they were sliced and the cores from the slices analyzed for $\mathrm{Cl}$ content. From these results, $D_{\text {app }}$ was approximated from solutions to Fick's $2^{\text {nd }}$ law using the error function. PPC at all w/c ratios showed lower $D_{\text {app }}$ than $\mathrm{OPC} . \mathrm{Cl}$ ingress for both cement types across all cement categories, increased with the increase in $w / c$ ratio.
\end{abstract}

Key Words: Diffusivity, Aggressive media, water/cement ratio, Compressive strength, Error function.

\section{Introduction}

An environment of between 20 to $50{ }^{\circ} \mathrm{C}$ and humidity of about $35-50$ percent with the presence of aggressive ions make concrete/mortar structures vulnerable to deterioration and as a result shorten their service life span [1,2]. Chloride and sulphate ions are common in many water masses, making them readily available to cement matrix either during cement paste making or to constructed cement structures [3].

Hydrated $\mathrm{OPC}$ has a resultant high $\mathrm{Ca}(\mathrm{OH})_{2}$, about 20 percent by weight, that makes it susceptible to the aggressive ions. Blending OPC with pozzolanic materials makes it less permeable, thus reducing the ingress of aggressive media [4]. The pozzolana reacts with the resultant $\mathrm{Ca}(\mathrm{OH})_{2}$ producing more cementitious material. This increases the compressive strength of resultant mortar/concrete, although after a longer period compared to OPC. The pozzolana thus improves on cement quality and reduces the $\mathrm{Ca}(\mathrm{OH})_{2}$ content, the most susceptible component.

Unavailability of sewerage drainage systems leads to use of septic tanks or simply pits, allowing waste water run-offs, as well as unauthorized/unsupervised construction procedures [5]. This exposes the constructed cement structures to aggressive media. When chloride ions ingress cement mortar or concrete, it has beneficial effect of enhancing residual cement hydration which in essence increases the cement strength but, the ions ingress has been shown to attack the reinforcing bar where corrosion may ensue. Corrosion of the rebar results in its strength failure. The corrosion products are expansive and may lead to sprawling and crack of the concrete $[1-3,6]$.

The aim of this study was to investigate the diffusivity of chloride ions and their effect on compressive strength development of selected Kenyan OPC and PPC mortars. Test cements were selected Kenyan OPC and PPC. The test cements were labeled with respect to company source and cement category; the letters A, B and C represented companies while $\mathrm{O}$ and $\mathrm{P}$ represented OPC and PPC respectively. AO for example, represents OPC from company A and AP represents PPC from company A.

\section{Experimental Procedure}

OPC and PPC cements were sampled from companies' appointed distributors in Kenyan major towns. Cements from three major cement making companies were used. $10 \mathrm{~kg}$ cement was bought from the appointed distributors in the three towns respectively. The sand as obtained from the sampling site was washed by spraying with tap water and sun-dried for three days to a constant weight as per ASTM C 0117 (2004). The dried sand was graded to meet the standard sand aggregates grade in accordance to ASTM C 1077 (2011).

Mortar preparation and curing was done in accordance to KS EAS 18:2008. Mortars of w/c ratio 0.55, 0.60 and 0.70 were prepared for both OPC and PPC. Mortars were labeled for identification as BO 05, BP 05, BO 06, BP 06, BO 07 and BP 07. The letter B in the label represent company B, O represents OPC, P represents PPC and 05 represent w/c ratio of 0.55 . Similar labeling was used for cements from companies A and C. In each 
cement category, 18 prisms were prepared. Compressive strength for the mortars was determined at the $7^{\text {th }}$ and $28^{\text {th }}$ day of curing.

About $100.00 \mathrm{~g}$ of cement sample for each category was separately ground to pass through a $76 \mu \mathrm{m}$ mesh sieve. The ground sample was used for the analysis of cement oxides using $\mathrm{x}$-ray fluorescence in the usual manner. The cement oxides analysed included $\mathrm{Na}_{2} \mathrm{O}, \mathrm{K}_{2} \mathrm{O}, \mathrm{CaO}, \mathrm{MgO}, \mathrm{SiO}_{2}, \mathrm{TiO}_{2}, \mathrm{Al}_{2} \mathrm{O}_{3}, \mathrm{Fe}_{2} \mathrm{O}_{3}$ and $\mathrm{MnO}_{2}$. Loss on Ignition was done in accordance to ASTM C 1157 (2004).

Diffusing test was done in accordance to ASTM C 1556 (2004). The cement mortar cured at 28 days was reduced to $100 \mathrm{~mm}$ length. An electrochemical cell was set-up in accordance to [7]. The mortar specimen was placed between two cells and covered with a fabric material. The set-up is shown in plate 2.1 (in appendix). The anodic compartment was filled with $500 \mathrm{ml}$ of water. An equal volume of $3.5 \% \mathrm{NaCl}$ was placed in the cathodic compartment. Stainless steel electrodes were placed separately in the compartments. The electrodes were connected to a $12 \pm 0.1 \mathrm{~V}$ direct current (DC) power source. The diffusion period started when the solutions in both the anodic and cathodic compartments were placed and the electrodes connected in circuit. The top of the container was then covered with a polyethylene paper and the entire set up maintained at $22 \pm 1$ ${ }^{\circ} \mathrm{C}$ for thirty six hours. During the experimental period, the solutions were stirred periodically using a glass rod. For every cement category 6 mortar prisms were subjected to Chloride ingress.

For each category of cement, three mortar cubes were subjected to compressive strength analysis while three mortar cubes for each ingress ion were sliced into $10 \mathrm{~mm}$ slices along the length using a water-lubricated cutting machine. Plate 2.2 (in appendix) shows the various mortar prism slices. A rotary hammer drill was used to drill through a circular portion of $25 \mathrm{~mm}$ from the centre of each mortar slice. The mortar obtained was ground to pass through a $76 \mu \mathrm{m}$ mesh sieve. The ground samples were then subjected to $\mathrm{Cl}^{-}$analysis. Triplicate analyses were done for each category of cement.

$\mathrm{Cl}^{-}$analysis was done in accordance to ASTM C 1552 (2005). Analysis for $\mathrm{Cl}^{-}$in standard solution and sample was analysed using chloride ion selective electrode in the usual manner. Calibration curves were used to determine the $\mathrm{Cl}^{-}$ion concentration in test solutions.

The results were presented in chloride concentration versus depth of cover. The chloride diffusion coefficients, $\mathrm{D}_{\mathrm{mig}}$, were derived from the solution to the second Fick's law of diffusion. The error fitting curves given as equation 2.1 in appendix using the method of least squares $[8,9]$ was used.

Since the chloride ion ingress was accelerated by a potential difference, then apparent diffusion coefficient, $\mathrm{D}_{\mathrm{app}}$, was obtained from equation 2.2 (in appendix) $[4,8,10]$.

\subsection{Chemical Analysis Results}

\section{Results And Discussion}

The results for the chemical analysis of oxides in percent by mass (except for $\mathrm{Cl}^{-}$) for various categories of cements are given in table 3.1 (in appendix).

All test cements were within the range prescribed by KS EAS 18 (2008). They are all suitable for the purpose they are designed for. PPC exhibited higher $\mathrm{Al}_{2} \mathrm{O}_{3}, \mathrm{SiO}_{2}$ and $\mathrm{Fe}_{2} \mathrm{O}_{3}$ contents than OPC. This can be attributed to added Pozzolana [11-13]. The presence of pozzolana in Portland cement enhances the chloride binding capacity of $\mathrm{C}_{3} \mathrm{~A}$ by reducing the alkalinity of the pore solution and presence of $\mathrm{Al}_{2} \mathrm{O}_{3}$ and $\mathrm{Fe}_{2} \mathrm{O}_{3}[2,9]$. The packing of pozzolana grains between cement hydration products decreases permeability of concrete / mortar [9]. Pozzolanic reaction leads to more CSH and CAH compounds which possess cementitious properties [13]

The results for the phase composition in per cent by mass for various categories of cements are given in table 3.2 (in appendix). The table shows the main cement phases from Bogue's calculations [14].

The various cements have the major cement phases within the Kenya Bureau of standards acceptable range (KS EAS 18, 2008). Typical OPC should have $\mathrm{C}_{3} \mathrm{~S}, \mathrm{C}_{2} \mathrm{~S}, \mathrm{C}_{4} \mathrm{AF}$ and $\mathrm{C}_{3} \mathrm{~A}$ within the range of $45-75$ percent, 7 - 32 percent, 0.6 - 18 percent and $0.5-13$ percent respectively (Mehta, 2011). PPC exhibited lower $\mathrm{C}_{3} \mathrm{~S}$ than OPC while the converse is true for $\mathrm{C}_{2} \mathrm{~S}$. Perhaps, the latter could be attributed to the silica content in pozzolana which is not accounted for in the Bogue's calculations. The test cement $\mathrm{CO}$ had extremely low $\mathrm{C}_{3} \mathrm{~S}$ content. Perhaps this could be attributed to the raw meal content.

\subsection{Compressive Strength at the $7^{\text {Th }}$ and $28^{\text {Th }}$ day}

Compressive strength results for various categories of cements at varied w/c ratio are represented in figure 3.1 (in appendix).

The compressive strength was observed to increase with curing age for all cement categories. Kenyan standard, KS EAS 168-1 (2008) requires that PPC have a minimum strength of $15 \mathrm{MPa}$ at the $7^{\text {th }}$ day of curing while at the $28^{\text {th }}$ day be at $32 \mathrm{MPa}$. OPC should have a minimum of $25 \mathrm{MPa}$ at the $7^{\text {th }}$ day while at the $28^{\text {th }}$ day it should have a minimum of $42.5 \mathrm{MPa}$ (KS02-1262, 1993). All cement samples had met the standard requirement.

Generally, OPC attains higher strength at early age compared to PPC [13]. This has been attributed to 
the slow strength development of the incorporated pozzolana in PPC [15]. OPC had a higher $\mathrm{C}_{3} \mathrm{~S}$ content than PPC. $\mathrm{C}_{3} \mathrm{~S}$ contributes to early strength development [7].

In all cement categories, it was observed that the higher the w/c ratio, the lower the compressive strength. The compressive strength for all mixes decreased with increasing w/c ratio. This is as would be expected [15]. The more the free water content of the fresh mortar the greater would be the volume of pores left in the hardened mortar and therefore the less the gel/space ratio. W/c ratio is therefore a measure of the void volume relative to the solid volume in hardened cement paste, and its strength goes up as the void volume goes down. So, the lower the w/c ratio, the lower is the void volume/solid volume, and the stronger the hardened cement paste. The higher hydration rate of OPC may have substantially reduced its porosity compared to the PPC. The beneficial effect of pozzolana blend may have been overridden by the porosity due to high w/c ratio $[6,15]$. [1 and 7] observed similar trends.

\subsection{Compressive strength Results for Test Cements after Subjecting to Chloride Solutions}

The percent gain in compressive strength for the various categories of cements at varied $w / c$ ratio after being subjected to $\mathrm{Cl}^{-}$are given in figure 3.2 (in appendix).

\subsection{Chloride Profiling}

Results for chloride ingress into selected OPC mortars at varied w/c ratio determined at varied depth of cover within the mortar are graphically presented in figure $3.3-3.4$ (in appendix).

In all cases, w/c ratio affected the ingress of the $\mathrm{Cl}^{-}$. The higher the w/c ratio, the higher the ingress. The trend correlates with that observed by [1]. The authors attributed this to continuous and interlinked voids through which the ions ingress.

The type of cement was predominant over the effect of w/c ratio in view of the extent of chloride ingress in all depths of cover. PPC exhibited lower chloride ingress than OPC at all depths of cover. PPC generally had higher $\mathrm{Al}_{2} \mathrm{O}_{3}$ content than OPC. $\mathrm{Al}_{2} \mathrm{O}_{3}$ is known to bind $\mathrm{Cl}^{-}$thus decreasing their ingress. This is mainly due to formation of Friedel's salt $[2,11]$. When more chlorides are bound, the diffusivity of chlorides is lowered [10]. Pozzolana improves the resistance of the blended cements. This is due to additional cementious material from pozzolanic reaction and the packaging of the pozzolana grain between aggregates and cement grains [3-5]. [7] observed that due to pozzolanic reactions, the pores become finer and hence the chloride diffusivity drops.

\subsection{Chloride Apparent Diffusivity Coefficients}

Results for the chloride error function fitting curve for $\mathrm{BO}$ and $\mathrm{BP}$ at w/c ratio 0.55 is presented in figure 3.5 and 3.6 (in appendix) respectively. Table 3.3 (in appendix) gives the $\mathrm{D}_{\text {app }}$ and $\mathrm{D}_{\text {mig }}$ with corresponding chloride surface concentration $\left(\mathrm{C}_{\mathrm{s}}\right)$ and $\mathrm{r}^{2}$ values of the error fitting curves.

PPC cement mortars exhibited lower apparent diffusion coefficient $\left(D_{\text {app }}\right)$ than OPC across all w/c ratios. As observed earlier from figures 3.3 and 3.4, PPC exhibited lower chloride ingress than OPC. Similar observations were made by [6]. [15] observed a similar scenario using ground granulated blast furnace slag (ggbs) as the pozzolana. [15] attributed this to the replacement of cementitious material with the pozzolanic material.

It was observed, as expected, that the higher the w/c ratio, the higher was the $\mathrm{D}_{\text {app. }}$. Again, as observed from figures 3.3 and 3.4, there was more chloride ingress in mortars with higher w/c ratio. This resulted in higher $\mathrm{D}_{\text {app. }}[6-8]$ observed a similar trend. This could be attributed to increased permeability due to high porosity. The $\mathrm{D}_{\text {app }}$ values in the range of $10^{-10}$ imply that the test cement mortars have the capacity to resist chloride penetration.

\section{Conclusions}

Despite the observed chloride ingress, as observed by many workers, the values of $D_{\text {app }}$ in the range observed are not worrying as this allows the cement to perform within the expected duration without failure or with minimal repair. $\mathrm{Cl}^{-}$acts as an early compressive strength accelerator as the compressive strength was found to increase after subjecting the mortars to $\mathrm{Cl}^{-}$media. But, care should be exercised while using the cements in reinforced construction where chlorides and /or other aggressive ions are known or expected to be present.

\section{Acknowledgement}

The laboratory work operations for this study were carried out at Kenya Ministry of Roads, Materials Research and Testing Department and at Kenya Ministry of Environment and Natural Resources, Geological and Mines Department. The authors wish to thank the technical staff from the two departments for their assistance in preparation and testing of mortar prisms and test ions profiling. 


\section{References}

[1]. Atkins, C.P.; Scantlebury, J.D.; Nedwell, P.J. and Blatch, S.P. (1996). Monitoring Chloride Concentrations in Hardened Cement Pastes Using Ion Selective Electrodes, CEM CONCR RES; 26: 319 - 324.

[2]. Hoff, G. C. (1991). Durability of offshore and marine concrete structures, in durability of concrete, ACP SP - 126, Detroit, Michigan, Pp. 33 - 53.

[3]. Tibbetts, D. C. (1968). Performance of concrete in sea water: Some examples from Halifax, N. S., Performance of concrete, Canadian Building series, No. 2 University of Toronto Press, Pp. $159-180$

[4]. Zang Ying and Shi Mei-lun, (2012). Experimental study of special grouting by AC Impendance Technique. Materials science, engineering and building Materials; 3: 11- 47.

[5]. NEMA, (2012). The state of sewerage systems in urban centers in Kenya by 2012; 3: $3-25$

[6]. Muthengia, W. J. (2009). Effects of Selected Aggressive Ions on Pozzolana Based Cement made from Industrial and Agricultural Wastes, Chemistry Department, Kenyatta University, Nairobi. Pp. 100 - 106.

[7]. Machard, J.; Gerald, B. and Delagrave, A. (1998). Ion transport mechanisms in cement based materials. Materials Science of concrete, Vol 5, American Ceramic Society, Pp. $307-400$.

[8]. Andrade, C.; Castellote, C.; Alonso, C. and Gonzalez, C. (1999). Non-steady-state Chloride diffusion coefficients obtained from migration and natural diffusion tests. Mater. Stuct. Pp. $21-28$.

[9]. Collepardi, M.; Marcialis, A. and Turriziani, R. (1972). Penetration of Chloride Ions into Cement Pastes and Concrete, American Ceramic Society; 55: 534-535.

[10]. Luping, T. and Gulikers, J. (2007) On the Mathematics of Time-Dependent Apparent Chloride Diffusion Coefficient in Concrete, Cement and Concrete Research; 37: 589-595.

[11]. Birnin-Yauri U. A. and Glasser, F. P. (1998) Friedel's salt, its solid solution and their role in chloride binding, Cement Concrete Research; 28: 1713 - 1724.

[12]. Rasheeduzzafar T.; Hussain, E. S. and Al-Saadoun, S. S. (2004). Pore solution composition of hydrated cement pastes with reference to corrosion resistance performance of reinforcing steel in concrete, $\mathrm{V}^{\text {etch }}$ Middle East NACE Corrosion Conference, Bahrain, 28-30 Oct., Pp. 386 - 399.

[13]. Mehta, P. K. (2011). Durability of concrete in marine environment - A review, performance of concrete in marine environment, ACI Pub.; SP 68: 1 - 15 August, 2011.

[14]. Bogue, R. H. (1947). The Chemistry of Portland cement, Reinhold Publishing Co., New York, Pp. 102 - 154.

[15]. Neville, A. (2008). International Union of Testing and research Laboratories for materials and structures. Construction Press, Lancaster, Pp. 531 - 539.

\section{APPENDIX}

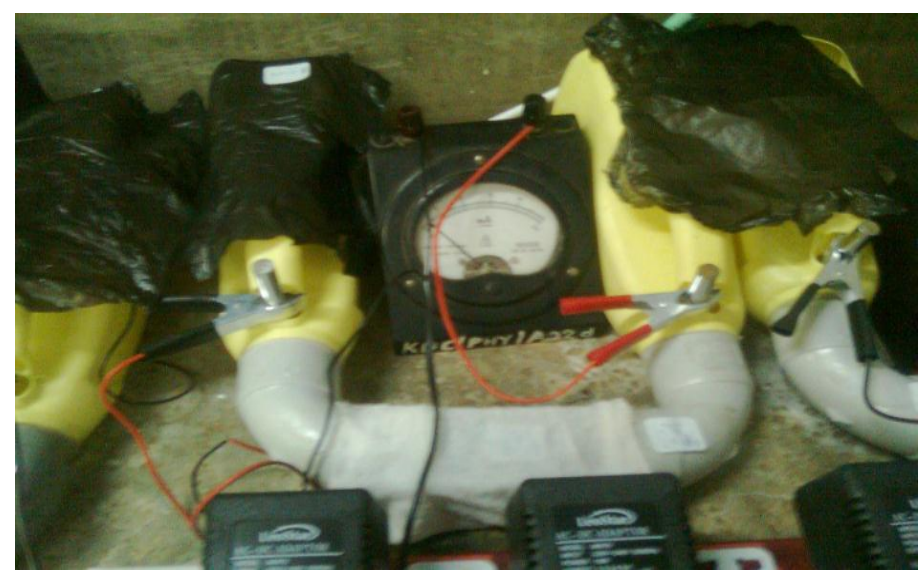

Plate 2.1: Accelerated Ion Migration Test Cell Set Up

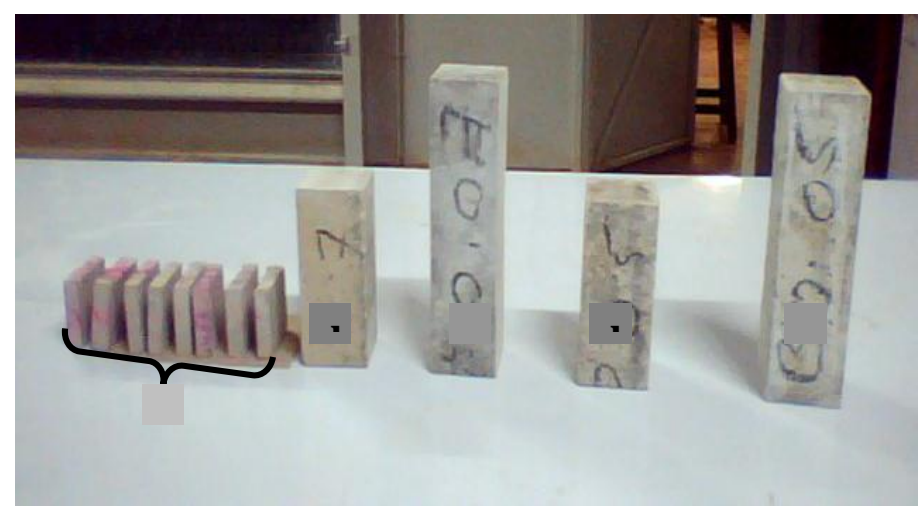

Plate 2.2: Sample Mortar Prisms and Slices

Key: a represents $160 \mathrm{~mm}$ prism before diffusion, b represents the sliced prism of $100 \mathrm{~mm}$ subjected to diffusivity test and $\mathbf{c}$ represents the $10 \mathrm{~mm}$ slices sliced from the $100 \mathrm{~mm}$ mortar prism after diffusion. 


\section{Equation 2.1}

$$
\frac{\mathrm{C}_{(\mathrm{x}, \mathrm{t})}}{\mathrm{C}_{\mathrm{s}}}=1-\operatorname{erf}\left(\frac{\mathrm{x}}{2 \sqrt{\mathrm{D}_{\text {migt }}}}\right)
$$

where $\operatorname{erf}(\mathrm{y})$ is the error function, $\mathrm{t}$ is the duration of exposure of the concrete sample, $\mathrm{x}$ is the distance from the exposed surface penetrated by the ion, $\mathrm{C}_{(\mathrm{x}, \mathrm{t})}$ is the ion concentration $(\mathrm{w} / \mathrm{w})$ at the distance $\mathrm{x}, \mathrm{C}_{\mathrm{s}}$ is the ion concentration at the exposed surface $(\mathrm{w} / \mathrm{w})$ and $\mathrm{D}_{\mathrm{mig}}$, is the Migration diffusion coefficient.

\section{Equation 2.2}

$$
\mathrm{D}_{\text {app }}=\frac{\mathrm{RT}}{\mathrm{z}_{\mathrm{i}} \mathrm{F}} \mathrm{D}_{\text {mig }} \frac{\mathrm{Int}^{2}}{\Delta \varnothing}
$$

where $\mathrm{R}$ is the Gas constant, $\mathrm{F}$ is the Faraday constant, $\mathrm{T}$ is the temperature of the electrolyte in $\mathrm{K}, \mathrm{z}_{\mathrm{i}}$ is the valency of the ion $i, \Delta \emptyset$ is the Effective Applied Voltage in $V, t$ is the duration of the test/exposure in seconds and $\mathrm{D}_{\text {app }}$ is the Apparent Diffusion coefficient.

Table 3.1: Chemical Analysis Results

\begin{tabular}{lrrrrrr}
\hline $\begin{array}{l}\text { Cement } \\
\text { metal Oxides } \\
\text { \% w/w } \pm \text { S.D. }\end{array}$ & \multicolumn{1}{c}{ BO } & \multicolumn{2}{c}{ BO } & \multicolumn{1}{c}{ AP } & \multicolumn{1}{c}{ CO } & CP \\
\hline $\mathbf{A l}_{\mathbf{2}} \mathbf{O}_{\mathbf{3}}$ & $3.417 \pm 0.150$ & $6.337 \pm 0.035$ & $3.980 \pm 0.010$ & $5.880 \pm 0.010$ & $4.323 \pm 0.021$ & $6.730 \pm 0.020$ \\
$\mathbf{S i O}_{\mathbf{2}}$ & $19.397 \pm 0.035$ & $38.640 \pm 0.036$ & $22.740 \pm 0.104$ & $35.320 \pm 0.036$ & $19.863 \pm 0.015$ & $32.680 \pm 0.030$ \\
$\mathbf{S O}_{\mathbf{3}}$ & $5.725 \pm 0.000$ & $1.661 \pm 0.000$ & $5.460 \pm 0.000$ & $3.133 \pm 0.000$ & $4.336 \pm 0.000$ & $3.622 \pm 0.000$ \\
$\mathbf{N a}_{\mathbf{2}} \mathbf{O}$ & $0.300 \pm 0.000$ & $0.910 \pm 0.010$ & $0.410 \pm 0.000$ & $0.883 \pm 0.006$ & $0.280 \pm 0.000$ & $1.057 \pm 0.006$ \\
$\mathbf{K}_{\mathbf{2}} \mathbf{O}$ & $0.463 \pm 0.006$ & $1.727 \pm 0.087$ & $0.667 \pm 0.006$ & $1.007 \pm 0.006$ & $0.710 \pm 0.000$ & $1.433 \pm 0.006$ \\
$\mathbf{C a O}$ & $65.867 \pm 0.058$ & $39.933 \pm 0.252$ & $63.100 \pm 0.436$ & $42.333 \pm 0.306$ & $54.400 \pm 0.361$ & $44.033 \pm 0.252$ \\
$\mathbf{M g O}$ & $0.990 \pm 0.020$ & $0.787 \pm 0.015$ & $2.113 \pm 0.025$ & $1.887 \pm 0.015$ & $0.933 \pm 0.006$ & $1.160 \pm 0.020$ \\
$\mathbf{F e}_{\mathbf{2}} \mathbf{O}_{\mathbf{3}}$ & $3.353 \pm 0.006$ & $5.093 \pm 0.015$ & $3.407 \pm 0.012$ & $4.320 \pm 0.036$ & $2.923 \pm 0.015$ & $4.537 \pm 0.025$ \\
$\mathbf{M n O}_{\mathrm{LOI}}$ & $0.100 \pm 0.000$ & $0.207 \pm 0.006$ & $0.173 \pm 0.006$ & $0.187 \pm 0.006$ & $0.300 \pm 0.000$ & $0.300 \pm 0.000$ \\
& $3.710 \pm 0.009$ & $3.710 \pm 0.009$ & $1.520 \pm 0.001$ & $3.910 \pm 0.003$ & $1.280 \pm 0.002$ & $3.060 \pm 0.003$ \\
\hline
\end{tabular}

Table 3.2 Phase Composition of Test Cements

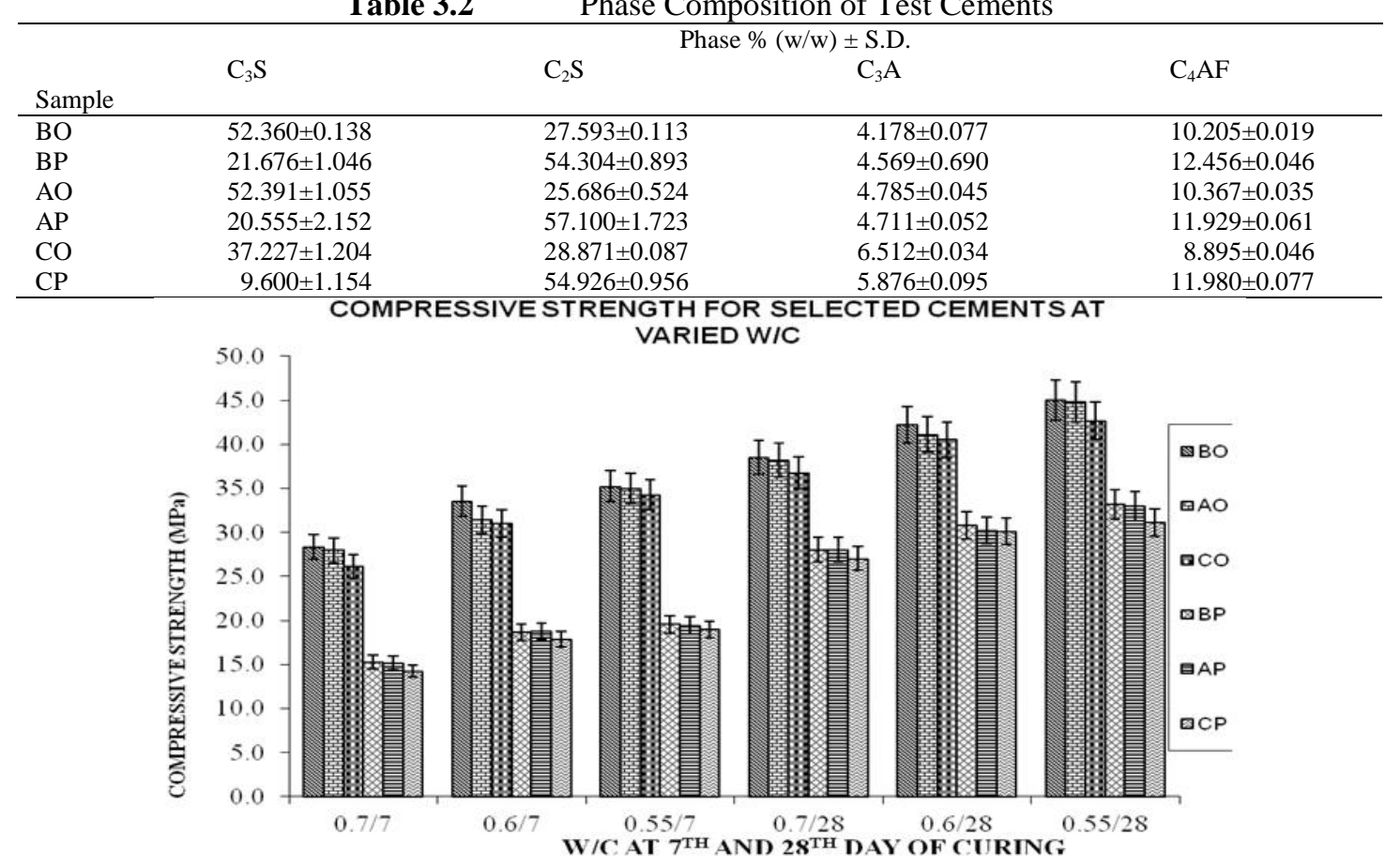

Figure 3.1: $\quad$ Compressive strength for selected cements at varied w/c ratio 
Key: $\quad 0.7 / 7$ represents test cement at w/c ratio 0.7 at $7^{\text {th }}$ day of curing, $0.7 / 28$ Represents test cement at w/c ratio 0.7 at $28^{\text {th }}$ day of curing, $\quad 0.6 / 7$ represents test cement at $w / c$ ratio 0.6 at $7^{\text {th }}$ day of curing, $0.6 / 28$ represents test cement at w/c ratio 0.6 at $28^{\text {th }}$ day of curing, $0.55 / 7$ represents test cement at w/c ratio 0.55 at $7^{\text {th }}$ day of curing while $0.55 / 28$ Represents test cement at w/c ratio 0.55 at $28^{\text {th }}$ day of curing.

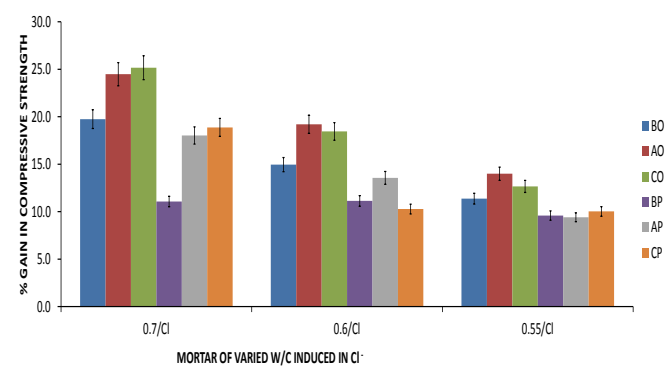

Figure 3.2 Percent gain in compressive strength for selected cements at varied w/c ratio in chloride solutions

Key: $\quad 0.7 / \mathrm{Cl}$ represents test cement at w/c ratio 0.7 ingress by $\mathrm{Cl}^{-}, 0.6 / \mathrm{Cl}$ represents test cement at w/c ratio 0.6 ingress by $\mathrm{Cl}^{-}, 0.55 / \mathrm{Cl}$ represents test cement at w/c ratio 0.55 ingress by $\mathrm{Cl}^{-}$.
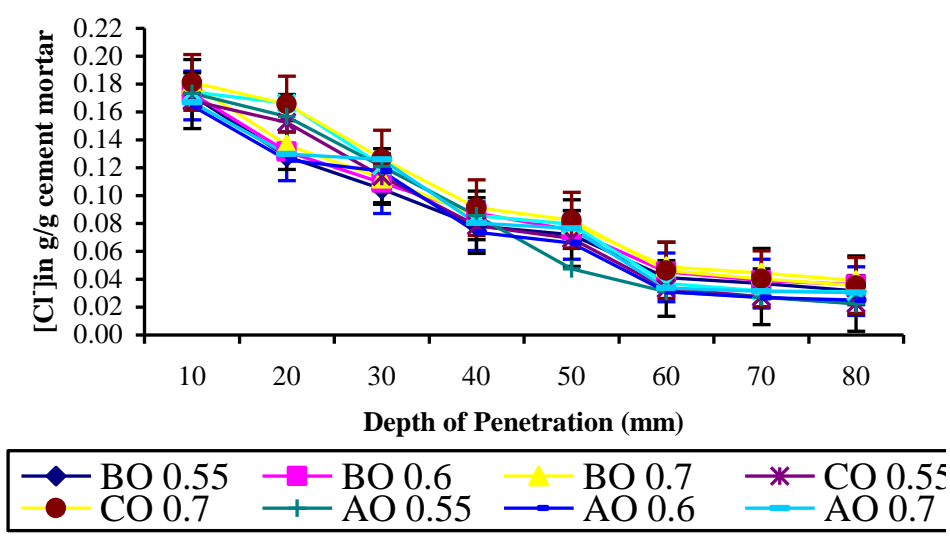

Figure 3.3: $\quad$ Chloride Profile for OPC against Depth of Cover

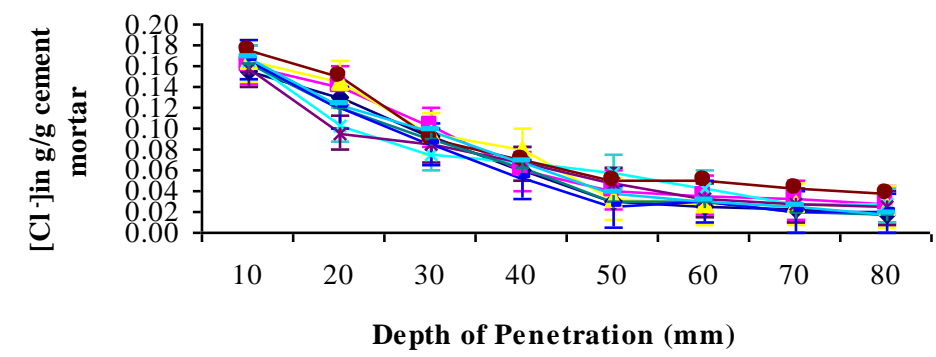

\begin{tabular}{llll}
$\longrightarrow$ BP 0.55 & - BP 0.6 & - BP 0.7 & - C \\
$\longrightarrow$ CP 0.7 & - AP 0.55 & - AP 0.6 & - A \\
\hline
\end{tabular}

Figure 3.4: $\quad$ Chloride Profile for PPC against Depth of Cover 

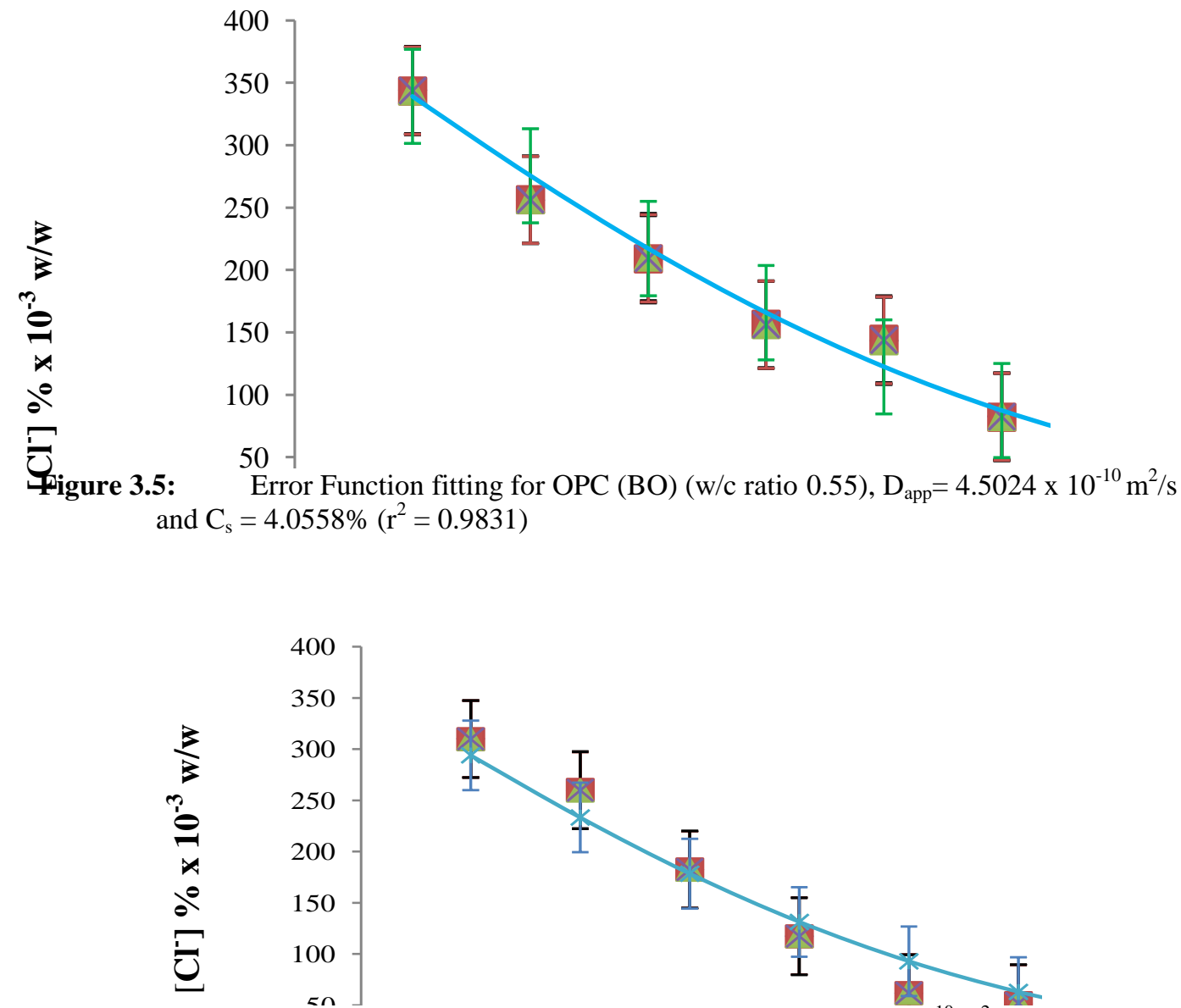

Figure 3.6: Error Function fitting for PPC (BP) (w/c ratio 0.55), $D_{\text {app }}=3.7708 \times 10^{-10} \mathrm{~m}^{2} / \mathrm{s}$ and $C_{\mathrm{s}}=3.5797 \%\left(\mathrm{r}^{2}\right.$ $=0.9772)$

Table 3.3: $D_{\text {mig }}, D_{\text {app }}$ and $r^{2}-$ Values for Different Cement Mortars at Different w/c ratio in $\mathrm{NaCl}$.

\begin{tabular}{|c|c|c|c|c|c|}
\hline $\begin{array}{c}\text { Cement } \\
\text { type }\end{array}$ & w/c & $D_{\text {mig }}\left(\times 10^{-9} \mathrm{~m}^{2} / \mathrm{s}\right)$ & $D_{\text {app }}\left(\times 10^{-10} \mathrm{~m}^{2} / \mathrm{s}\right)$ & $\mathbf{r}^{2}-$ Value & $\mathrm{C}_{\mathrm{s}}(\%)$ \\
\hline \multirow{3}{*}{$\mathrm{BO}$} & 0.7 & 9.7790 & 4.8608 & 0.9815 & 4.2806 \\
\hline & 0.6 & 9.4792 & 4.7118 & 0.9868 & 4.1506 \\
\hline & 0.55 & 9.0581 & 4.5024 & 0.9831 & 4.0558 \\
\hline \multirow{3}{*}{$\mathrm{AO}$} & 0.7 & 9.4792 & 4.7118 & 0.9625 & 4.0104 \\
\hline & 0.6 & 9.3659 & 4.6555 & 0.9756 & 3.8387 \\
\hline & 0.55 & 8.3901 & 4.1704 & 0.9785 & 4.2198 \\
\hline \multirow{3}{*}{$\mathrm{CO}$} & 0.7 & 9.8613 & 4.9017 & 0.9830 & 4.4273 \\
\hline & 0.6 & 9.6147 & 4.7791 & 0.9694 & 4.3555 \\
\hline & 0.55 & 9.1123 & 4.5294 & 0.9829 & 4.0950 \\
\hline \multirow{3}{*}{ BP } & 0.7 & 8.1384 & 4.0453 & 0.9628 & 4.0914 \\
\hline & 0.6 & 8.0893 & 4.0209 & 0.9629 & 3.8504 \\
\hline & 0.55 & 7.5862 & 3.7708 & 0.9772 & 3.5797 \\
\hline \multirow{3}{*}{$\mathrm{AP}$} & 0.7 & 7.9210 & 3.9372 & 0.9859 & 3.7107 \\
\hline & 0.6 & 7.3126 & 3.6348 & 0.9668 & 3.5675 \\
\hline & 0.55 & 7.2841 & 3.6207 & 0.9812 & 3.5755 \\
\hline \multirow{3}{*}{$\mathrm{CP}$} & 0.7 & 9.4498 & 4.6971 & 0.9321 & 3.9366 \\
\hline & 0.6 & 8.0279 & 3.9904 & 0.9540 & 3.5783 \\
\hline & 0.55 & 7.7905 & 3.8724 & 0.8783 & 3.9649 \\
\hline
\end{tabular}

